\title{
Maximum efficiency concentration of indole butyric acid in promoting the rooting of Japanese Flowering Cherry
}

\section{Rosimeri de Oliveira Fragoso ${ }^{1^{*}}$ Carlos André Stuepp ${ }^{1}$ Helena Cristina Rickli ${ }^{1}$ Katia Christina Zuffellato-Ribas ${ }^{2}$ Henrique Soares Koehler ${ }^{1}$}

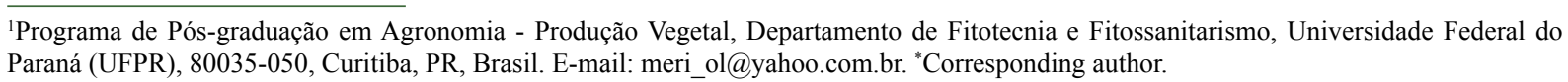
${ }^{2}$ Centro Politécnico, Setor de Ciências Biológicas, Departamento de Botânica, Universidade Federal do Paraná (UFPR), Curitiba, PR, Brasil.

ABSTRACT: Prunus serrulata is a species widely used in the ornamentation and its economic importance is mainly due to the time of its flowering. The objective was to assess the feasibility of cutting technique for propagating $\boldsymbol{P}$. serrulata, using stem cuttings from current-year shoots, and to estimate the maximum efficiency concentration of auxin indole butyric acid (IBA), in the promotion of rooting. Collection of plant material took place in late spring. Cuttings were made with about $8 \pm 1 \mathrm{~cm}$ length and two leaves reduced to $50 \%$ of its original surface. Twenty one IBA concentrations have been assessed (0, 250, 500, 750, 1000, 1250, 1500, 1750, 2000, 2250, 2500, 2750, 3000, 3250, 3500, 3750, 4000, 4250, 4500, 4750 e 5000 $\left.\mathrm{mg} \mathrm{L}^{-1}\right)$, applied in base of cuttings, which were placed in acclimatized greenhouse. After 60 days, there was a gradual increase in the rooting percentage compared to the increment of IBA to the approximate concentration of $2700 \mathrm{mg} L^{-1}$, with results higher than $80 \%$. In addition, low efficiency concentrations of growth regulators have resulted in fewer roots per cutting, which could compromise the survivability of the seedlings under ambient conditions. Conversely, the decrease in the percentage of callus may be an indication that root formation in P. serrulata occurs directly, without requiring callus formation and its further de-differentiation and re-differentiation in roots. Key words: current-year shoots, cutting technique, ornamental species, Prunus serrulata, regression analysis.

\section{Concentração de máxima eficiência de ácido indol butírico} na promoção do enraizamento de cerejeira-do-Japão

RESUMO: Prunus serrulata é uma espécie muito empregada na ornamentação e sua importância econômica deve-se principalmente à ocasião de sua floração. Objetivou-se avaliar a viabilidade da técnica de estaquia para a propagação de P. serrulata, utilizando-se estacas caulinares provenientes de brotações do ano, bem como estimar a concentração de máxima eficiência da auxina ácido indol butírico (AIB), na promoção do enraizamento. A coleta do material vegetativo ocorreu no final da primavera. As estacas foram confeccionadas com cerca de $8 \pm 1$ cm de comprimento e duas folhas reduzidas a 50\% de sua superficie original. Foram avaliadas 21 concentrações de AIB (0, 250, 500, 750, 1000, 1250, 1500, 1750, 2000, 2250, 2500, 2750, 3000, 3250, 3500, 3750, 4000, 4250, 4500, 4750 e 5000mg L-1), aplicadas na base das estacas, as quais foram acondicionadas em casa de vegetação climatizada. Após 60 dias, verificou-se um aumento gradativo do percentual de enraizamento em relação ao incremento de AIB até a concentração aproximada de $2700 \mathrm{mg} \mathrm{L}^{-1}$, com resultados superiores a 80\%. Ademais, concentrações de baixa eficiência do regulador vegetal resultaram em menor número de raizes por estaca, o que poderia comprometer a capacidade de sobrevivência das mudas em condições ambientais. Por outro lado, o descréscimo do percentual de calos pode ser um indicativo de que a formação de raizes em P. serrulata ocorra de maneira direta, sem a necessidade de formação de calos e sua posterior desdiferenciação e rediferenciação em raizes. Palavras-chave: brotações do ano, estaquia, espécie ornamental, Prunus serrulata, análise de regressão.

\section{INTRODUCTION}

The species Prunus serrulata Lindl., belonging to the Rosaceae family, has its natural occurrence in Asia, being popularly known as Japanese Flowering Cherry. Prunus serrulata Lindl. is a deciduous tree, which reaches 4-6 meters high, with cylindrical trunk covered with a rough and lenticel gray-purple skin colored (LORENZI et al., 2003). This species has exuberant flowering, why it is widely used in landscaping, especially in urban forestry (MONDIN et al., 2010).

The reproduction of this species is often accomplished through seeds (LORENZI et al.,
2003), not having enough information about its spread through asexual, which could facilitate the acquisition of seedlings, allowing selection of genotypes of interest (BEYL \& SHARMA, 2014). Among the vegetative propagation techniques used for ornamental plants, cutting technique is the most widely employed for cloning of woody species on a large scale (GRATIERI-SOSSELLA et al., 2008).

The production of seedlings by the plant macropropagation is characterized by the induction of root formation of cuttings and is subject to intrinsic characteristics of each species, as the 
amount of endogenous auxin (ABU-ZAHRA et al., 2013). Environmental factors such as temperature, rainfall and photoperiod can influence the amount of free auxin on mother plants (NEGISHI et al., 2014), determining unsatisfactory levels for rooting (OSTERC \& STAMPAR, 2011).

In view of this, one way to facilitate the process of rooting cuttings refers to the use of plant growth regulators such as synthetic auxins, which can induce root formation, forming more uniform and vigorous roots, accelerating the process of formation of the seedlings (PIZZATTO et al., 2011; POP et al., 2011). The addition of auxin has been verified in many works and the necessary concentrations vary from species to species (ABU-ZAHRA et al., 2013). Generally, plants progressively respond to stimulation until an appropriate level of auxin, from which the increase in concentration becomes inhibitory or even phytotoxic (POP et al., 2011).

Thus, this study aimed to evaluate the viability of cutting technique in the vegetative propagation of $\boldsymbol{P}$. serrulata, using stem cuttings with leaves, from current-year shoots, and to estimate the concentration of maximum efficiency of synthetic auxin indole butyric acid (IBA) to promote the rooting of these.

\section{MATERIALS AND METHODS}

The collection of plant material of $\boldsymbol{P}$. serrulata occurred in Curitiba (PR) $\left(25^{\circ} 25^{\prime} 40^{\prime \prime} \mathrm{S}\right.$ e $\left.49^{\circ} 16^{\prime} 23^{\prime \prime} \mathrm{W}\right)$. The climate is characterized as temperate $(\mathrm{Cfb})$ according to Köppen classification, with average temperatures around $18^{\circ} \mathrm{C}$, with a maximum of $22^{\circ} \mathrm{C}$ and minimum of $13^{\circ} \mathrm{C}$, temperatures remained low until mid-spring. The relative humidity is around $82 \%$ and rainfall generally higher than $1.300 \mathrm{~mm}$, without defined dry season (IAPAR, 2015).

The material consists of current-year shoots collected by late spring, from 20 mother plants with approximately five years old, five meters high and diameter at breast height (DBH) of $15 \mathrm{~cm}$, planted on conditions of full sun. Semihard wood stem cuttings were made with $8 \pm 1 \mathrm{~cm}$ long, with cut beveled at the bottom and right above the last apical bud, keeping two leaves reduced to $50 \%$ of its original surface.

Cuttings received phytosanitary treatment with sodium hypochlorite at $0.5 \%$ for 10 minutes (bactericidal effect), subsequently washed in running water for 10 minutes. Immediately afterwards it was proceeded treatment with different concentrations of indole butyric acid (IBA) P.A. $\left(\right.$ Merck $^{\circledR}$ ) on base of cuttings for 10 seconds immersion (STUEPP et al., 2014). Concentrations used were: 0, 250, 500, $750,1000,1250,1500,1750,2000,2250,2500$, 2750, 3000, 3250, 3500, 3750, 4000, 4250, 4500, 4750 e $5000 \mathrm{mg} \mathrm{L}^{-1}$ (water-alcohol solution $1: 1 \mathrm{v} / \mathrm{v}$ ). The control treatment of cuttings $\left(0 \mathrm{mg} \mathrm{L}^{-1}\right)$ were immersed in distilled water and alcohol solution 98\% (1:1 v/v). The cuttings planting was performed in polypropylene small tubes with $55 \mathrm{~cm}^{3}$, filled with average particle size of vermiculite and carbonized rice husk $(1: 1 \mathrm{v} / \mathrm{v})$. The experiment was conducted in an acclimatized greenhouse, with an intermittent mist, average temperature of $24 \pm 2^{\circ} \mathrm{C}$ and $85 \%$ relative humidity.

After 60 days of experiment installation, the following variables were evaluated (FRAGOSO et al., 2015): percentage of rooted cuttings (alive cuttings that presented roots at least $2 \mathrm{~mm}$ long); number of roots per cutting (counting the number of primary roots); length of the three longest roots per cutting $(\mathrm{cm})$; percentage of cuttings with callus (alive cuttings, without roots, with undifferentiated cells formation on the base); percentage of survival (alive cuttings, without roots or callus formation); percentage of mortality (cuttings with dead tissues); percentage of cuttings with sprouting (live cuttings which presented sprouts of at least $2 \mathrm{~mm}$ in length); percentage of original leaves maintenance (live cuttings who had maintaining at least one original leaf).

The experimental design was completely randomized with 21 treatments (IBA concentrations) and 4 replications of 20 cuttings per each experimental unit, totaling 1680 cuttings. Variances of the treatments were evaluated regarding homogeneity by the Bartlett test $(p<0.05)$. For qualitative data variables that showed significant differences $(p<0.05)$ in the analysis of variance (ANOVA) had their averages compared by Tukey test at $5 \%$ probability (BITENCOURT et al., 2009). For quantitative data, the results were submitted to polynomial regression analysis $(\mathrm{p}<0.01$ e $\mathrm{p}<0.05)$ (BRONDANI et al., 2010).

\section{RESULTS AND DISCUSSION}

According to the analysis of variance there was no significant effect of the application of IBA on vegetative material of $\boldsymbol{P}$. serrulata $(\mathrm{p}<0.05)$ for all variables, except for the survival percentage (Table 1). According to the polynomial regression analysis the significant effect of IBA on rooting demonstrated a gradual increase of rooted cuttings in 
Table 1 - Summary of the analysis of variance (ANOVA) for the variables percentage of rooting (PR), callus formation (CF), survival (CS), mortality (CM), sprouting (S) and maintenance of original leaves (ML), number of roots per cutting (NRC) and average length of roots per cutting (LRC) of $\boldsymbol{P}$. serrulata, submitted to different concentrations of IBA.

\begin{tabular}{|c|c|c|c|c|c|c|c|c|c|}
\hline \multirow{3}{*}{ S.V. } & \multirow{3}{*}{ D.F. } & \multicolumn{8}{|c|}{ - } \\
\hline & & PR & $\mathrm{CF}$ & CS & $\mathrm{CM}$ & $\mathrm{S}$ & ML & NRC & LRC \\
\hline & & & & & & & ----- & $\left(\mathrm{n}^{\circ}\right)$ & $(\mathrm{cm})$ \\
\hline IBA & 20 & $1381.01^{* *}$ & $265.80^{* *}$ & $247.17^{\mathrm{ns}}$ & $620.30^{* *}$ & $514.32^{* *}$ & $897.89^{* *}$ & $7.17^{* *}$ & $6.63^{* *}$ \\
\hline ERROR & 63 & 227.38 & 101.69 & 230.65 & 266.27 & 200.50 & 391.77 & 2.23 & 3.22 \\
\hline TOTAL & 83 & - & - & - & - & - & - & - & - \\
\hline
\end{tabular}

S.V.: Source of variation; D.F.: Degree of freedom; ${ }^{* *}$ Significant at $1 \%$ probability; ${ }^{*}$ Significant at $5 \%$ probability; ${ }^{\text {ns }}$ Not significant at $1 \%$ and $5 \%$ probability.

relation to the increase in plant growth regulator to the concentration of $2680.78 \mathrm{mg} \mathrm{L}^{-1}\left(\mathrm{r}^{2}=0.6665\right.$ and $\mathrm{p}<0.0001$ ), generating a percentage higher than $80 \%$ (Figure 1a). Based on this concentration, there is a decrease in the percentage of rooting, signaling that exogenous auxin concentration reached its point of maximum efficiency, going to be inhibitory to the species $\boldsymbol{P}$. serrulata (HARTMANN et al., 2011; POP et al., 2011). The correlation coefficient between the percentage of rooting and application of IBA obtained from the regression analysis showed a value of $r=0.8164$.

The inhibitory effect caused by excessive application of IBA has been observed in other species of the genus Prunus (MINDÊLLO NETO et al., 2005; MINDÊLLO NETO et al., 2006), in some cases with concentration limits close to the obtained in the present study $\left(2700 \mathrm{mg} \mathrm{L}^{-1}\right)$. However, this concentration is variable depending on the content of endogenous auxin in each species (ABU-ZAHRA et al., 2013), which varies depending on the age (OSTERC \& STAMPAR, 2011), physiological conditions (PERROT-RECHENMANN, 2010; WENDLING et al., 2014), genetic of mother plant (POP et al., 2011) and time of year (OLIVEIRA \& RIBEIRO, 2013). When the endogenous auxin content is insufficient, the application of less sensible synthetic auxin to biological degradation, such as IBA, it is important to promote a proper hormonal balance that favors the rooting of cuttings, as was observed in this study. The percentage of cuttings rooting with IBA application was significantly higher than that obtained without its application, demonstrating the importance of synthetic auxin for the production of clonal plants of $\boldsymbol{P}$. serrulata.

In an inverse manner the results obtained for the formation of roots, there was a decrease in the percentage of cuttings with callus formation as far as it increased the concentrations of IBA (Figure 1b). The highest percentage was observed in the concentration of $0 \mathrm{mg} \mathrm{L}^{-1}(28 \%)$ and the lowest percentage in the concentrations of $3500 \mathrm{mg}$ $\mathrm{L}^{-1}$, 4000mg L $\mathrm{m}^{-1}$ and $4500 \mathrm{mg} \mathrm{L}^{-1}(0 \%)$. According to the adjusted equation $\left(r^{2}=0.64\right.$ and $\left.r=0.80\right)$, the minimum estimated point for the percentage of callus formation is achieved in the concentration of $3325 \mathrm{mg} \mathrm{L}^{-1}$ (Figure 1b), from which the percentages tend to increase gradually.

Rooting percentage increase due to higher concentrations of IBA, conversely, a decrease in the percentage of callus may be an indication that root formation in $\boldsymbol{P}$. serrulata occurs directly, without requiring the formation of callus and later differentiation and re-differentiation of these in roots. This indicator can be checked also when considering the fact that, regardless of IBA concentrations, there are higher percentages of live or dead cuttings (Figure 1c, 1d) in comparison to the cuttings with calluses. These results have often been observed for other tree species as Melaleuca alternifolia (STUEPP et al., 2013), and shrub, as Calliandra brevipes and $\boldsymbol{C}$. tweedii (MAYER et al., 2008).

For the other variables, the coefficient of determination $\left(\mathrm{r}^{2}\right)$ and correlation coefficient (r) in the adjusted regression equations had low values, not showing reliability of the regression equations to explain the responses of the features measured against the IBA applications. However, the lowest percentage mortality occurred at concentrations with higher percentage of rooting, enabling the use of IBA.

Similarly, the variables emission of sprouts incuttings and maintenance of originalleaves presented statistically significance between the concentrations of IBA. For both, the highest percentages $(68 \%$ and $85 \%$, respectively) were obtained at a concentration 


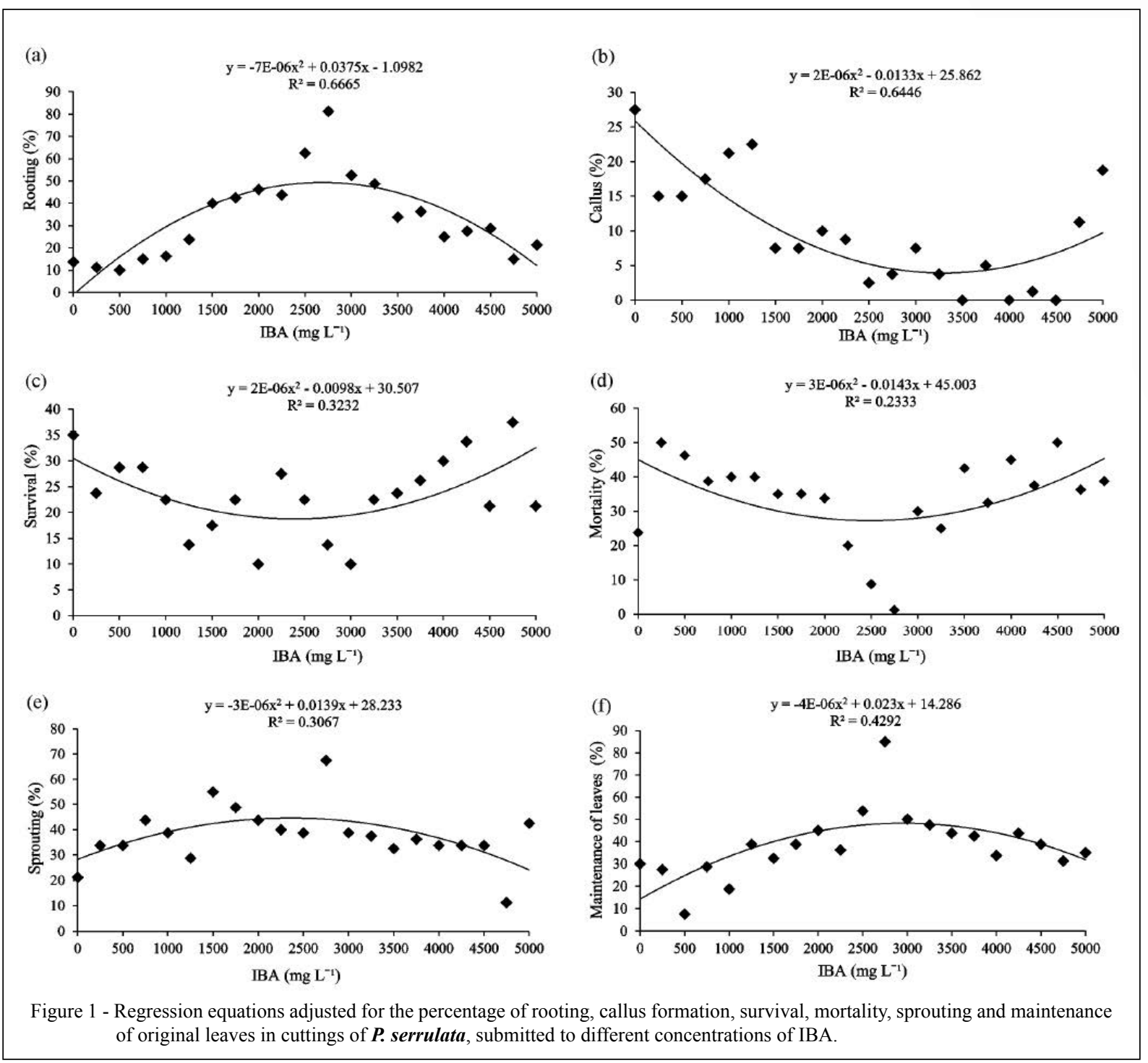

of $2750 \mathrm{mg} \mathrm{L}^{-1}$, corresponding also to the largest rooting (Figure 1e, 1f). According to Pearson correlation coefficients, a significant correlation between the variable percentage of rooting and shoots emission was reported $(\rho=0.65 ; p<0.01)$ and also the maintenance of the original leaves $(\rho=0.88 ; \mathrm{P}<0.01)$.

The high correlation between the percentage of rooting and maintenance of the original leaves demonstrated the importance of the leaves for the provision of further metabolites synthesized on mother plant (RUEDELL et al., 2013). Permanence of leaves on stem cuttings has been referred as an important factor both for survival and for rooting (BEYL \& SHARMA, 2014; FERREIRA et al., 2014). All leaves are producer of carbohydrates, plant hormones and rooting cofactors, which are provided to the cuttings by the polar transport, raising their concentrations on the basis of these (PERROTRECHENMANN, 2010; NEGISHI et al., 2014).

Positive correlations were also observed between the number and average length of roots and shoots, likewise for Prunus persica in order to evaluate the feasibility of propagation of Nemared, Flordaguard and Okinawa rootstocks cultivars (TIMM et al., 2015). According to the authors, the higher was the number and average length of roots, the greater the number and length of shoots, which would indicate a balance of these variables, which are parameters of vigor and quality of seedlings.

These results are in agreement with the one obtained in this research for the number of roots per cutting, since it has been reported that the absence 
or low concentration of IBA (250 and 500mg L $\left.\mathrm{L}^{-1}\right)$ differed statistically from the concentration of $3000 \mathrm{mg} \mathrm{L}^{-1}$, which has the highest average for this variable $\left(5,58\right.$ roots cutting $\left.^{-1}\right)$ (Table 2$)$. Concentration close to that provided the highest percentages of emission of shoots and leaves maintenance. As the number of roots per cutting is related to the potential issue of adventitious roots in a certain time period, it is observed that the non-application of plant growth regulator or applications of low efficiency levels in $\boldsymbol{P}$. serrulata may result in plants with less survivability when subjected to environmental conditions. However, higher averages has also been reported in other species, such as 7.5 roots per cutting at a concentration of $3000 \mathrm{mg} \mathrm{L}^{-1}$ for Prunus persica cultivate Della Nona (RIBAS et al., 2007). In relation to the average length of roots per cutting, there was a good radicial development for all IBA concentrations, with the highest values obtained in concentrations of $750 \mathrm{mg} \mathrm{L}^{-1}$ and $1000 \mathrm{mg} \mathrm{L}^{-1}$ $(6.91 \mathrm{~cm}$ and $7.15 \mathrm{~cm}$, respectively) (Table 2$)$.

Table 2 - Average of variables number of roots per cutting (NRC) and average length of roots per cutting (LRC) of $\boldsymbol{P}$. serrulata, submitted to different concentrations of IBA.

\begin{tabular}{lll}
\hline IBA & NRC & LRC \\
\hline $\mathrm{mg} \mathrm{L}^{-1}$ & $\left(\right.$ cutting $\left.^{-1}\right)$ & $(\mathrm{cm})$ \\
0 & $1.0 \mathrm{~d}$ & $3.9 \mathrm{ab}$ \\
250 & $1.5 \mathrm{bcd}$ & $4.5 \mathrm{ab}$ \\
\hline 500 & $1.4 \mathrm{~cd}$ & $1.4 \mathrm{~b}$ \\
750 & $3.1 \mathrm{abcd}$ & $6.9 \mathrm{a}$ \\
1000 & $2.4 \mathrm{abcd}$ & $7.1 \mathrm{a}$ \\
\hline 1250 & $4.3 \mathrm{abcd}$ & $6.1 \mathrm{ab}$ \\
1500 & $3.1 \mathrm{abcd}$ & $5.7 \mathrm{ab}$ \\
1750 & $3.5 \mathrm{abcd}$ & $5.8 \mathrm{ab}$ \\
\hline 2000 & $4.8 \mathrm{abcd}$ & $4.8 \mathrm{ab}$ \\
2250 & $3.2 \mathrm{abcd}$ & $5.1 \mathrm{ab}$ \\
2500 & $2.8 \mathrm{abcd}$ & $4.9 \mathrm{ab}$ \\
\hline 2750 & $3.8 \mathrm{abcd}$ & $4.7 \mathrm{ab}$ \\
\hline 3000 & $5.6 \mathrm{a}$ & $4.0 \mathrm{ab}$ \\
3250 & $5.0 \mathrm{abc}$ & $4.3 \mathrm{ab}$ \\
\hline 3500 & $3.9 \mathrm{abcd}$ & $4.7 \mathrm{ab}$ \\
\hline 3750 & $3.1 \mathrm{abcd}$ & $4.5 \mathrm{ab}$ \\
\hline 4000 & $4.2 \mathrm{abcd}$ & $5.2 \mathrm{ab}$ \\
4250 & $5.0 \mathrm{abc}$ & $4.7 \mathrm{ab}$ \\
\hline 4500 & $5.3 \mathrm{ab}$ & $3.8 \mathrm{ab}$ \\
\hline 4750 & $2.3 \mathrm{abcd}$ & $2.6 \mathrm{ab}$ \\
\hline 5000 & $4.9 \mathrm{abc}$ & $4.5 \mathrm{ab}$ \\
\hline $\mathrm{CV}(\%)$ & 42.24 & \\
\hline & & \\
\hline & & \\
\hline
\end{tabular}

Averages followed by the same letter in the column are not statistically different from each other, by Tukey test at $5 \%$ probability.

\section{CONCLUSION}

The conditions in which the present research was performed, the use of cuttings from current-year shoots is suitable for the rooting of $\boldsymbol{P}$. serrulata. The leaf maintenance is essential for the technical feasibility and IBA application for the promotion of rooting, being recommended concentration of approximately $2700 \mathrm{mg} \mathrm{L}^{-1}$.

\section{ACKNOWLEDGEMENTS}

We would like to thank the Study and Research de Pesquisa em enraizamento de estacas (GEPE) of the Universidade Federal do Paraná (UFPR) and to Coordenação de Aperfeiçoamento Pessoal de Nível Superior (CAPES) for granting doctoral scholarships.

\section{REFERENCES}

ABU-ZAHRA, T.R. et al. Influence of auxin concentrations on different ornamental plants rooting. International Journal of Botany, v.9, n.2, p.96-99, 2013. Available from: <http://docsdrive. com/pdfs/ansinet/ijb/2013/96-99.pdf>. Accessed: June 17, 2015. doi: $10.3923 / \mathrm{ijb} .2013 .96 .99$.

BEYL, C.A.; SHARMA, G.C. Plant physiology concepts important for propagation success. In: BEYL, C.A.; TRIGIANO, R.N. Plant propagation concepts and laboratory exercises. New York: CRC, 2014. p.29-46.

BITENCOURT, J. et al. Rooting of "erva-mate" (Ilex paraguariensis A. St.-Hill.) cuttings from rejuvenated sprouts. Revista Brasileira de Plantas Medicinais, v.11, n.3, p.277-281, 2009. Available from: $<$ http://www.scielo.br/pdf/rbpm/v11n3/08.pdf>. Accessed: June 17, 2015. doi: 10.1590/S1516-05722009000300008.

BRONDANI, G.E. et al. IBA application for rooting of Eucalyptus benthamii Maiden \& Cambage x Eucalyptus dunnii Maiden minicuttings. Acta Scientiarum. Agronomy, v.32, n.4, p.667674, 2010. Available from: <http://www.scielo.br/pdf/asagr/ v32n4/a14v32n4.pdf $>$. Accessed: June 17, 2015. doi: 10.4025/ actasciagron.v32i4.4879.

FERREIRA, B.G.A. et al. Psychotria nuda (Cham. \& Schltdl.) Wawra: rooting of stock plants in different phenophases and environments. Ciência Florestal, v.24, p.367-378, 2014. Available from: <http://www.bioline.org.br/pdf?cf14036>. Accessed: June 17, 2015. doi: 10.5902/19805098145744.

FRAGOSO, R.O. et al. Vegetative propagation of Juniperus chinensis. Comunicata Scientae, v.6, n.3, p.307-316, 2015. Available from: <https://comunicatascientiae.com.br/comunicata/article/ view/825/348>. Accessed: June 17, 2015. doi: 10.14295/CS.v6i3.825.

GRATIERI-SOSSELLA, A. et al. Propagation of swamp corticeira (Erythrina crista-galli L.) (Fabaceae) by the cutting technique. Revista Árvore, v.32, n.1, p.163-171, 2008. Available from: $<$ http://www.scielo.br/readcube/epdf.php?doi=10.1590/S010067622008000100018\&pid=S0100-67622008000100018\&pdf path $=$ rarv/v32n1/18.pdf\&lang=pt $>$. Accessed: June 17, 2015. doi: 10.1590/S0100-67622008000100018. 
HARTMANN, H.T. et al. Hartmann \& Kerster's plant propagation: principles and practices. New Jersey: Prentice Hall, 2011. 915p

IAPAR (INSTITUTO AGRONÔMICO DO PARANÁ). Cartas climáticas do Paraná. Online. Available from: $<$ http://www.iapar.br/ modules/conteudo/conteudo.php?conteudo $=863>$. Accessed: October 20,2015 .

LORENZI, H. et al. Árvores exóticas do Brasil: madeireiras, ornamentais e aromáticas. Nova Odessa: Instituto Platarum, 2003. 384p.

MAYER, J.L.S. et al. Root formation in cuttings of two species of Calliandra (Leguminosae - Mimosoideae). Rodriguésia, v.59, n.3, p.487-495, 2008. Available from: $<$ http://rodriguesia.jbrj.gov. br/FASCICULOS/rodrig59_3/006.pdf >. Accessed: June 17, 2015.

MINDÊLLO NETO, U.R. et al. Rooting of nectarine semi-hardwood cuttings treated with different concentrations of indolbutiric acid. Current Agricultural Science and Technology, v.11, n.3, p.299301, 2005. Available from: $<\mathrm{http}: / /$ periodicos.ufpel.edu.br/ojs2/index. php/CAST/article/view/1257/1048>. Accessed: June 17, 2015. doi: 10.18539/CAST.V11I3.1257.

MINDÊLLO NETO, U.R. et al. Rooting of hardwood cuttings from plum treated with indolbutiric acid. Ciência Rural, n.36, n.2, p.448-452, 2006. Available from: <http://www.scielo.br/pdf/cr/v36n2/a14v36n2.pdf >. Accessed: June 17, 2015. doi: 10.1590/S0103-84782006000200014.

MONDIN, C.A. et al. Catálogo ilustrado de plantas - espécies ornamentais da PUCRS. Porto Alegre: EDIPUCRS, 2010. 127p.

NEGISHI, N. et al. Hormone level analysis on adventitious root formation in Eucalyptus globulus. New Forests, v.45, p.577-587, 2014. Available from: <http://www.researchgate. net/publication/261178996_Hormone_level_analysis_on_ adventitious root formation in Eucalyptus_globulus $>$. Accessed: June 17, 2015. doi: 10.1007/s11056-014-9420-1.

OLIVEIRA, M.C.; RIBEIRO, J.F. Rooting cuttings of Euplassa inaequalis (pohl) engl. in Gallery Forest specie in different seasons. Bioscience Journal, v.29, n.4, p.991-999, 2013. Available from: <http://www.seer.ufu.br/index.php/biosciencejournal/article/ view/15203/12920>. Accessed: June 17, 2015.

OSTERC, G.; ŠTAMPAR, F. Differences in endo/exogenous auxin profile in cuttings of different physiological ages. Journal of Plant Physiology, v.168, p.2088-2092, 2011. Available from: <http:// www.sciencedirect.com/science/article/pii/S0176161711003427>. Accessed: June 17, 2015. doi: 10.1016/j.jplph.2011.06.016.

PERROT-RECHENMANN, C. Cellular responses to auxin: division versus expansion. Cold Spring Harbor Perspectives in
Biology, v.2, n.5, p.a001446, 2010. Available from: <http://www. ncbi.nlm.nih.gov/pmc/articles/PMC2857164/>. Accessed: June 18, 2015. doi: 10.1101/cshperspect.a001446.

PIZZATTO, M. et al. Effects of IBA concentration, collection time and cutting length on hibiscus cutting propagation. Revista Ceres, v.58, n.4, p.487-492, 2011. Available from: $<$ http://www.scielo.br/ pdf/rceres/v58n4/a13v58n4.pdf $>$. Accessed: June 18, 2015. doi: 10.1590/S0034-737X2011000400013.

POP, T.I. et al. Auxin control in the formation of adventitious roots. Notulae Botanicae Horti Agrobotanici, v.39, n.1, p.307-316, 2011. Available from: $<$ http://www.notulaebotanicae.ro/index. php/nbha/article/view/6101/5593>. Accessed: June 18, 2015. doi: $10.15835 /$ nbha3916101

RUEDELL, C.M. et al. Pre and post-severance effects of light quality on carbohydrate dynamics and microcutting adventitious rooting of two Eucalyptus species of contrasting recalcitrance. Plant Growth Regulation, v.69, n.3, p.235-245, 2013. Available from: $<$ http://link. springer.com/article/10.1007\%2Fs10725-012-9766-3>. Accessed: June 18, 2015. doi: 10.1007/s10725-012-9766-3.

RIBAS, C.P. et al. Indolbutiric acid in rooting semihardwood cuttings of Dellanona and Eldorado peach cultivars. Scientia Agraria, v.8, n.4, p.439-442, 2007. Available from: <http:// ojs.c3sl.ufpr.br/ojs/index.php/agraria/article/view/9894/8081>. Accessed: June 18, 2015. doi: 10.5380/rsa.v8i4.9894.

STUEPP, C.A. et al. Rooting of tea tree: influence of cutting collection height and IBA application. Colloquium Agrariae, v.9, n.1, p.01-09, 2013. Available from: <http://revistas.unoeste.br/ revistas/ojs/index.php/ca/article/view/850/980>. Accessed: June 18, 2015. doi: 10.5747/ca.2013.v09.n1.a083.

STUEPP, C.A. et al. Vegetative propagation of mature dragon trees through epicormic shoots. Revista Bosque, v.35, n.3, p.333-341, 2014. Available from: <http://mingaonline.uach.cl/pdf/bosque/ v35n3/art08.pdf>. Accessed: June 18, 2015. doi: 10.4067/S071792002014000300008 .

TIMM, C.R.F. et al. Rooting of herbaceous minicuttings of peach rootstock under effect of indolebutyric acid (IBA). Semina, v.36, n.1, p.135-140, 2015. Available from: <http://www.uel.br/revistas/ uel/index.php/semagrarias/article/view/14885/pdf_570>. Accessed: June 18, 2015. doi: 10.5433/1679-0359.2015v36n1p135.

WENDLING, I. et al. Maturation and related aspects in clonal forestry - Part I: concepts, regulation and consequences of phase change. New Forest, v.45, n.4, p.449-471, 2014. Available from: <http://link.springer.com/article/10.1007\%2 Fs11056-014-9421-0>. Accessed: June 18, 2015. doi: 10.1007/ s11056-014-9421-0. 